Adrenal glands

asphyxia

brain

circulatory response fetus

heart newborn monkey phenobarbital

\title{
The Effect of Phenobarbital on Asphyxia in the Newborn Monkey
}

\author{
DAVID E. FISHER, ${ }^{(21)}$ JOHN B. PATON, AND RICHARD E. BEHRMAN \\ Department of Pediatrics, Michael Reese Medical Center, Chicago, Illinois, USA
}

\section{Extract}

This study characterizes the circulatory changes associated with asphyxia in the newborn monkey and examines the effect of phenobarbital on asphyxia. The time to last gasp and duration of total asphyxia as well as heart rate at the start of resuscitation were the same in the phenobarbital-treated and untreated infants. Initial cardiac output was the same in both groups; there was a profound drop in cardiac output with asphyxia which was the same in both groups. Organs which preferentially receive a greater percentage of cardiac output during asphyxia are heart, total brain, and adrenal glands. Organs receiving a decreased percentage of cardiac output during asphyxia are kidneys, liver, and gastrointestinal tract. Cerebral hemisphere flow as a percentage of cardiac output is maintained during asphyxia, whereas paleoencephalon flow as a percentage of cardiac output increases significantly. These data confirm the circulatory redistribution of cardiac output in response to asphyxia described previously in the monkey fetus. The treated infants did not show the prolongation of time to last gasp reported in the monkey fetus; the dose of phenobarbital we used, although adequate to produce sedation, may have been too low to demonstrate the protective effect.

\section{Speculation}

The long term survival status of infants with neonatal diseases such as severe meconium aspiration or hyaline membrane disease which are frequently accompanied by varying degrees of asphyxia might be improved by including phenobarbital in the treatment regimen if a protective effect were conclusively demonstrated.

The purpose of this study was to characterize the circulatory changes associated with asphyxia in the newborn monkey and to examine the effect of a barbiturate, phenobarbital, on asphyxia. Pentobarbital, used in anesthetic doses in the pregnant rhesus monkey near term, exerts a protective effect against asphyxia initiated at delivery of the fetus as measured by prolongation of the time to last gasp, accelerated establishment of rhythmic breathing after resuscitation, and less histologic evidence of permanent brain damage (3). Redistribution of the circulation in response to asphyxia has been demonstrated in the monkey fetus (1); an increased percentage of oxygenated blood was directed to heart muscle and brain. This paper presents the first quantitative information available on the circulatory response to asphyxia in the newborn nonhuman primate.

\section{METHODS}

Fourteen newborn monkeys (Macaca speciosa) born at term (by weight and physical assessment) in the Primate Breeding
Facility of the University of Illinois were studied between 1 and 8 days after spontaneous vaginal delivery. Six infants were untreated and eight received phenobarbital during the experimental protocol; all other aspects of the protocol were the same for every infant in the study. The age distribution of the two groups was comparable.

Polyvinyl catheters were placed in the left ventricle, descending aorta at the level of the diaphragm, and inferior vena cava at the level of the right atrium via the femoral vessels. The left ventricle catheter placement was verified by use of a pressure transducer or x-ray. After surgery the infant was positioned prone over a rolled towel and permitted to recover in an incubator overnight (7). Glucose (10\%) in water, $100 \mathrm{ml} / \mathrm{kg} / 24 \mathrm{hr}$, was given intravenously and antibiotics (penicillin and kanamycin) were given intramuscularly. The treated infants received $10 \mathrm{mg} / \mathrm{kg}$ phenobarbital intramuscularly a few hours after surgery and early the next morning, approximately $4 \mathrm{hr}$ before asphyxiation, for a total dose of 20 $\mathrm{mg} / \mathrm{kg}$ in an $18 \mathrm{hr}$ period.

The initial determination of acid-base and oxygenation status, cardiac output, and organ blood flows were made approximately $2 \mathrm{hr}$ before asphyxiation. After these procedures the infant was permitted to recover for over $1 \mathrm{hr}$ and acid-base parameters and $\mathrm{O}_{2}$ consumption were again measured (pre-asphyxia). Then the infant was asphyxiated by inserting and blocking an endotracheal tube. Heart rate, respiratory effort, gasping, and apnea were all noted. After 5 min of total asphyxia, cardiac output and organ blood flows were measured. This was followed as soon as possible by withdrawal of blood for acid-base estimations. The duration of asphyxia was thus $8-10 \mathrm{~min}$ and was followed by an attempted resuscitation using positive pressure $\mathrm{O}_{2}$ and intravenous sodium bicarbonate $(3 \mathrm{mEq} / \mathrm{kg})$. Infants with a sustained increase in heart rate over 100 beats/min were considered survivors.

Arterial blood pressure and heart rate were measured with a Sanborn physiologic monitoring system (12). Blood samples were obtained from femoral artery and vein for each determination of acid-base and oxygenation status; blood was replaced with maternal blood. Blood $\mathrm{pH}$ was measured with a Radiometer electrode and PHM 71 meter which was calibrated with buffer solutions at pH 7.381 and 6.840 before and after each sample (13). $\mathrm{P}_{\mathrm{O}_{2}}$, was measured polarographically with a modified Clark electrode calibrated with saturated gas mixtures at $38^{\circ} . \mathrm{P}_{\mathrm{CO}_{2}}$, bicarbonate, and base deficit were calculated using the Siggaard-Anderson nomogram (10). Oxygen consumption (5) was measured with a Kipp universal diaferometer (14).

Cardiac output and organ blood flows were determined using a modification (4) of the radionuclide-labeled microsphere method of Rudolph and Heymann (9). Radionuclidelabeled microspheres (15), $50 \mu \mathrm{m}$ in diameter, were slowly injected into the left ventricle; at the same time blood was withdrawn over $1 \mathrm{~min}$ from the descending aorta using a 
constant speed pump (16). Blood and organ radioactivity was measured with a multichannel $\gamma$ counter (17). Since adequate mixing of microspheres and blood has been shown to take place in the left ventricle (8), the relation between blood flow and radioactivity can be expressed as equation 1 .

Left ventricular output $(\mathrm{LVO})(\mathrm{ml} / \mathrm{min})=$ rate of withdrawal of aortic blood $(\mathrm{ml} / \mathrm{min})$ $\gamma$ activity of blood withdrawn from aorta

$$
X \text { total body } \gamma \text { activity }
$$

Cardiac output represents effective systemic flow of oxygenated blood and therefore is represented by left ventricular output minus left to right shunt through the ductus arteriosus (equation 2). A right to left shunt was not measured but it was assumed to be small since $\mathrm{P}_{\mathrm{O}_{2}}$ of blood obtained from the descending aorta was high with the infant breathing room air. In addition, where it was possible to obtain blood both from the left ventricle and the descending aorta, the $\mathrm{P}_{\mathrm{O}_{2}}$ measurements were not different.

Cardiac output $(\mathrm{CO})(\mathrm{ml} / \mathrm{min})=$

$$
\begin{aligned}
& \frac{\text { rate of withdrawal of aortic blood }(\mathrm{ml} / \mathrm{min})}{\gamma \text { activity of blood withdrawn from aorta }} \\
& \quad \times \text { total body } \gamma \text { activity minus lung } \gamma \text { activity }
\end{aligned}
$$

Derivation of organ blood flow is shown in equation 3 and expressed as a percentage of cardiac output in equation 4.

Organ blood flow $(\mathrm{ml} / \mathrm{min})=$

$$
\begin{aligned}
& \frac{\text { organ } \gamma \text { activity }}{\text { total body } \gamma \text { activity minus lung } \gamma \text { activity }} \times \mathrm{CO} \\
& \% \mathrm{CO} \text { to organ }= \\
& \frac{\text { organ } \gamma \text { activity }}{\text { total body } \gamma \text { activity minus lung } \gamma \text { activity }} \times 100
\end{aligned}
$$

Sufficient microspheres $(20,000-25,000)$ were injected each time to insure that the organ distribution of cardiac output to all organs receiving at least $2 \%$ of the injected dose was measured within $10 \%$ of the mean at the $95 \%$ confidence level (2).

\section{RESULTS}

The initial status of the two groups of infants is described in Tables 1 and 2 . These data reveal no significant differences between the two groups in the measurements made; however, by clinical assessment all but one of the treated infants appeared to be sedated. The acid-base and oxygenation status of the two groups were the same, initially and during asphyxiation, as shown in Table 2. Additional assessment of blood pressure, acid-base, and oxygenation status and oxygen consumption just before asphyxiation did not differ significantly from the initial values.

Table 3 describes the clinical measurements in response to total asphyxia of the two groups of animals. The time to last gasp and duration of total asphyxia as well as heart rate at the start of resuscitation were the same in the phenobarbitaltreated and untreated infants. The incidence of survival after resuscitation was the same in both groups.

Cardiac output data is shown in Table 4. Initial cardiac output was the same in both groups; there was a profound drop in cardiac output with asphyxia which was comparable in both groups. In general the magnitude of the left to right shunt as a percentage of cardiac output was similar for both estimations of cardiac output in each animal. The range of shunt values was from $0-35 \%$ of the left ventricular output.

The organ distribution of cardiac output is shown in Tables 4-6. Blood flow to all organs was decreased during asphyxia. Table 4 indicates the organs which preferentially received a greater percentage of cardiac output during asphyxia: heart, total brain, and adrenal glands. Although adrenal blood flows were significantly different, no $P$ value has been assigned because the percentage of $\mathrm{CO}$ was less than $2 \%$ (2). Table 5 indicates the organs that received a decreased percentage of cardiac output during asphyxia: kidneys, liver, and gastrointestinal tract. Table 6 separates total brain into cerebral hemispheres and paleoencephalon (brainstem, midbrain, and cerebellum) and indicates that cerebral hemisphere flow, as a percentage of cardiac output, was maintained during asphyxia, whereas paleoencephalon flow, as a percentage of cardiac output, increased significantly. There was no significant difference in any of the organ flows between the untreated and treated group of infants.

\section{DISCUSSION}

The measurements of cardiac output and organ blood flow during asphyxia were made during an unsteady state and therefore may have less quantitative validity than the preasphyxia measurements. However, the decrease in cardiac output in response to a "standard" asphyxial stress was of a similar magnitude in all animals studied. Organ blood flow distributions showed similar homogeneity for each organ that received enough microspheres for statistical evaluation (2).

One of the factors that may make the neonate more

Table 1. Initial data on infants ${ }^{1}$

\begin{tabular}{|c|c|c|c|c|c|}
\hline $\begin{array}{l}\text { Monkey } \\
\text { group } \\
\text { (no.) }\end{array}$ & $\begin{array}{c}\text { Heart rate } \\
\text { after total } \\
\text { asphyxia } \\
\text { for } 5 \text { min, } \\
\text { beats } / \mathrm{min}\end{array}$ & $\begin{array}{c}\text { Time } \\
\text { to last } \\
\text { gasp, } \\
\text { sec }\end{array}$ & $\begin{array}{c}\text { Duration } \\
\text { of total } \\
\text { asphyxia, } \\
\text { sec }\end{array}$ & $\begin{array}{c}\text { Heart rate } \\
\text { at start of } \\
\text { resuscitation, } \\
\text { beats } / \mathrm{min}\end{array}$ & $\begin{array}{c}\text { Survival, } \\
\%\end{array}$ \\
\hline Untreated (6) & 70 & 348 & 569 & 52 & 67 \\
\hline$\pm \mathrm{SD}$ & 11 & 137 & 60 & 14 & \\
\hline Treated (8) & 60 & 328 & 531 & 53 & 75 \\
\hline$\pm \mathrm{SD}$ & 22 & 77 & 55 & 24 & \\
\hline
\end{tabular}

\begin{tabular}{ccrccc}
\hline $\begin{array}{c}\text { Monkey } \\
\text { group } \\
\text { (no.) }\end{array}$ & $\begin{array}{l}\text { Age, } \\
\text { days }\end{array}$ & Wt, g & $\begin{array}{c}\text { Systolic arterial } \\
\text { blood pressure, } \\
\mathrm{mm} \mathrm{Hg}\end{array}$ & $\begin{array}{c}\mathrm{O}_{2} \text { con- } \\
\text { sumption, } \\
\mathrm{ml} / \mathrm{min} / \mathrm{kg}\end{array}$ & $\begin{array}{c}\text { Cardiac } \\
\text { output, } \\
\mathrm{ml} / \mathrm{min} / \mathrm{kg}\end{array}$ \\
\hline $\begin{array}{c}\text { Untreated (6) } \\
\pm \text { SD }\end{array}$ & 3.3 & 488 & 76 & 12.2 & 154 \\
$\begin{array}{c}\text { Treated (8) } \\
\pm \text { SD }\end{array}$ & 5.2 & 35 & 10 & 3.6 & 59 \\
& 1.8 & 590 & 77 & 9.6 & 162 \\
\end{tabular}

${ }^{1}$ Values presented are means $\pm 1 \mathrm{SD}$

Table 2. Acid-base and oxygenation status ${ }^{1}$

\begin{tabular}{lcrrcr}
\hline $\begin{array}{c}\text { Monkey } \\
\text { group } \\
\text { (no.) }\end{array}$ & $\mathrm{pH}$ & $\begin{array}{c}\mathrm{P}_{\mathrm{O}_{2}} \\
\mathrm{~mm} \mathrm{Hg}\end{array}$ & $\begin{array}{c}\mathrm{P}_{\mathrm{CO}_{2}} \\
\mathrm{~mm} \mathrm{Hg}\end{array}$ & $\begin{array}{c}\text { Base } \\
\text { deficit, } \\
\mathrm{mEq} / \text { liter }\end{array}$ & $\begin{array}{c}\text { Actual } \\
\text { bicarbonate, } \\
\mathrm{mEq} / \text { liter }\end{array}$ \\
\hline $\begin{array}{l}\text { Untreated (6) } \\
\text { Initial }\end{array}$ & 7.38 & 98 & 32 & 3.6 & 19.5 \\
$\pm \mathrm{SD}$ & 0.03 & 15 & 3 & 2.4 & 2.3 \\
Asphyxia & 6.85 & 12 & 76 & $>22$ & 15.6 \\
$\pm \mathrm{SD}$ & 0.09 & 7 & 41 & & 4.0 \\
Treated (8) & & & & & \\
Initial & 7.40 & 94 & 34 & 2.6 & 20.8 \\
$\pm \mathrm{SD}$ & 0.02 & 7 & 3 & 1.5 & 1.7 \\
Asphyxia & 6.88 & 8 & 85 & $>22$ & 13.1 \\
$\pm \mathrm{SD}$ & 0.08 & 3 & 29 & & 3.2 \\
\hline
\end{tabular}

${ }^{1}$ Values presented are means $\pm 1 \mathrm{SD}$

Table 3. Clinical evaluation of asphyxia ${ }^{1}$

${ }^{1}$ Values presented are means $\pm 1 \mathrm{SD}$. 
Table 4. Cardiac output and organ blood flow ${ }^{1}$

\begin{tabular}{|c|c|c|c|c|c|c|c|}
\hline \multirow{2}{*}{$\begin{array}{c}\text { Monkey } \\
\text { group } \\
\text { (no.) }\end{array}$} & \multirow[b]{2}{*}{$\begin{array}{l}\mathrm{CO}, \mathrm{mg} / \\
\mathrm{min} / \mathrm{kg}\end{array}$} & \multicolumn{2}{|c|}{ Heart } & \multicolumn{2}{|c|}{ Total brain } & \multicolumn{2}{|c|}{ Adrenal gland } \\
\hline & & $\begin{array}{c}\mathrm{ml} / \\
\mathrm{min} / \mathrm{g}\end{array}$ & $\begin{array}{r}\% \\
\mathrm{CO}\end{array}$ & $\begin{array}{c}\mathrm{ml} / \\
\mathrm{min} / \mathrm{g}\end{array}$ & $\begin{array}{r}\% \\
\mathrm{CO}\end{array}$ & $\begin{array}{c}\mathrm{ml} / \\
\mathrm{min} / \mathrm{g}\end{array}$ & $\begin{array}{r}\% \\
\mathrm{CO}\end{array}$ \\
\hline \multicolumn{8}{|c|}{ Untreated (6) } \\
\hline \multicolumn{8}{|c|}{ Initial } \\
\hline Mean & 154 & 1.03 & 3.9 & 0.28 & 23.9 & 1.27 & 0.6 \\
\hline$\pm \mathrm{SD}$ & 59 & 0.21 & 1.1 & 0.07 & 5.6 & 0.40 & 0.2 \\
\hline \multicolumn{8}{|l|}{ Asphyxia } \\
\hline Mean & 19 & 0.71 & 18.6 & 0.05 & 31.1 & 0.23 & 1.4 \\
\hline$\pm \mathrm{SD}$ & 6 & 0.59 & 9.8 & 0.02 & 9.1 & 0.08 & 0.5 \\
\hline$P$ & $<0.05$ & NS & $<0.05$ & $<0.05$ & NS & & \\
\hline \multicolumn{8}{|l|}{ Treated (8) } \\
\hline \multicolumn{8}{|l|}{ Initial } \\
\hline Mean & 162 & 2.30 & 6.0 & 0.33 & 22.2 & 2.34 & 0.7 \\
\hline$\pm \mathrm{SD}$ & 44 & 2.78 & 3.4 & 0.16 & 4.4 & 1.61 & 0.2 \\
\hline Asphyxia & 21 & 0.44 & 11.6 & 0.06 & 32.4 & 0.98 & 1.8 \\
\hline$\pm \mathrm{SD}$ & 10 & 0.41 & 7.4 & 0.03 & 14.3 & 0.89 & 1.1 \\
\hline$P$ & $<0.05$ & NS & NS & $<0.05$ & NS & & \\
\hline
\end{tabular}

${ }^{1} \mathrm{CO}$ : cardiac output. Values presented are means $\pm 1 \mathrm{SD}$. Confidence levels of $95 \%$ were used in a two-sided $t$ test of significance. NS: not statistically significant. No $P$ values are given under adrenal glands (see text for explanation).

Table 5. Organ blood flow ${ }^{1}$

\begin{tabular}{|c|c|c|c|c|c|c|}
\hline \multirow{2}{*}{$\begin{array}{c}\text { Monkey } \\
\text { group } \\
\text { (no.) }\end{array}$} & \multicolumn{2}{|c|}{ Kidneys } & \multicolumn{2}{|c|}{ Liver } & \multicolumn{2}{|c|}{ GI tract } \\
\hline & $\begin{array}{c}\mathrm{ml} / \\
\mathrm{min} / \mathrm{g}\end{array}$ & $\% \mathrm{CO}$ & $\begin{array}{c}\mathrm{ml} / \\
\mathrm{min} / \mathrm{g}\end{array}$ & $\% \mathrm{CO}$ & $\begin{array}{c}\mathrm{ml} / \\
\mathrm{min} / \mathrm{g}\end{array}$ & $\% \mathrm{CO}$ \\
\hline \multicolumn{7}{|c|}{ Untreated (6) } \\
\hline \multicolumn{7}{|l|}{ Initial } \\
\hline Mean & 2.25 & 9.8 & 0.60 & 10.9 & 0.57 & 6.9 \\
\hline$\pm \mathrm{SD}$ & 0.55 & 1.2 & 0.14 & 2.2 & 0.16 & 0.9 \\
\hline \multicolumn{7}{|l|}{ Asphyxia } \\
\hline Mean & 0.07 & 2.3 & 0.04 & 2.5 & 0.02 & 1.3 \\
\hline$\pm \mathrm{SD}$ & 0.05 & 1.2 & 0.04 & 0.4 & 0.01 & 0.6 \\
\hline$P$ & $<0.05$ & $<0.05$ & $<0.05$ & $<0.05$ & $<0.05$ & $<0.05$ \\
\hline \multicolumn{7}{|l|}{ Treated (8) } \\
\hline \multicolumn{7}{|l|}{ Initial } \\
\hline Mean & 2.89 & 12.4 & 0.68 & 9.9 & 0.51 & 6.5 \\
\hline$\pm \mathrm{SD}$ & 1.34 & 5.2 & 0.55 & 3.4 & 0.32 & 1.5 \\
\hline \multicolumn{7}{|l|}{ Asphyxia } \\
\hline Mean & 0.10 & 3.0 & 0.03 & 4.2 & 0.02 & 2.0 \\
\hline$\pm \mathrm{SD}$ & 0.08 & 2.3 & 0.02 & 3.0 & 0.02 & 1.4 \\
\hline$P$ & $<0.05$ & $<0.05$ & $<0.05$ & $<0.05$ & $<0.05$ & $<0.05$ \\
\hline
\end{tabular}

${ }^{1}$ GI tract: gastrointestinal tract; $\mathrm{CO}$ : cardiac output. Values presented are means $\pm 1 \mathrm{SD}$. Confidence levels of $95 \%$ were used in a two-sided $t$ test of significance.

resistant to the effects of asphyxia is the influence of barbiturate on oxygen consumption (11). The treated infants in our study were clinically sedated; mean oxygen consumption was lower than in the control group although the difference was not statistically significant. Satisfactory oxygen consumption measurements were not technically possible during asphyxia with the method employed; oxygen consumption and metabolic rate may be more accurate measurements of barbiturate effect than prolongation of time to last gasp or other clinical parameters. Individual organ oxygen consumption measurements may be necessary to show differences between the two groups, inasmuch as oxygen consumption (11) and metabolic rate (6) have been demonstrated to be
Table 6. Brain blood flow ${ }^{1}$

\begin{tabular}{|c|c|c|c|c|c|c|}
\hline \multirow{2}{*}{$\begin{array}{c}\text { Monkey } \\
\text { group } \\
\text { (no.) }\end{array}$} & \multicolumn{2}{|c|}{ Total brain } & \multicolumn{2}{|c|}{$\begin{array}{c}\text { Cerebral } \\
\text { hemispheres }\end{array}$} & \multicolumn{2}{|c|}{ Paleoencephalon } \\
\hline & $\begin{array}{c}\mathrm{ml} / \\
\mathrm{min} / \mathrm{g}\end{array}$ & $\% \mathrm{CO}$ & $\begin{array}{c}\mathrm{ml} / \\
\mathrm{min} / \mathrm{g}\end{array}$ & $\% \mathrm{CO}$ & $\begin{array}{c}\mathrm{ml} / \\
\mathrm{min} / \mathrm{g}\end{array}$ & $\% \mathrm{CO}$ \\
\hline \multicolumn{7}{|c|}{ Untreated (6) } \\
\hline \multicolumn{7}{|c|}{ Initial } \\
\hline Mean & 0.28 & 23.9 & 0.28 & 18.9 & 0.31 & 4.2 \\
\hline$\pm \mathrm{SD}$ & 0.07 & 5.6 & 0.07 & 3.9 & 0.07 & 1.6 \\
\hline \multicolumn{7}{|c|}{ Asphyxia } \\
\hline Mean & 0.05 & 31.1 & 0.03 & 16.8 & 0.13 & 11.0 \\
\hline$\pm \mathrm{SD}$ & 0.02 & 9.1 & 0.02 & 7.4 & 0.08 & 4.2 \\
\hline$P$ & $<0.05$ & NS & $<0.05$ & NS & $<0.05$ & $<0.05$ \\
\hline \multicolumn{7}{|c|}{ Treated (8) } \\
\hline \multicolumn{7}{|l|}{ Initial } \\
\hline Mean & 0.33 & 22.2 & 0.31 & 17.7 & 0.41 & 5.2 \\
\hline$\pm \mathrm{SD}$ & 0.16 & 4.4 & 0.16 & 3.9 & 0.19 & 2.4 \\
\hline \multicolumn{7}{|c|}{ Asphyxia } \\
\hline Mean & 0.06 & 32.4 & 0.04 & 19.2 & 0.16 & 13.2 \\
\hline$\pm \mathrm{SD}$ & 0.03 & 14.3 & 0.03 & 10.8 & 0.09 & 5.8 \\
\hline$P$ & $<0.05$ & NS & $<0.05$ & NS & $<0.05$ & $<0.05$ \\
\hline
\end{tabular}

${ }^{1} \mathrm{CO}$ : cardiac output. Values presented are means $\pm 1 \mathrm{SD}$. Confidence levels of $95 \%$ were used in a two-sided $t$ test of significance. NS: not statistically significant.

lower in brain after barbiturate pretreatment. Our treated infants did not show the prolongation of time to last gasp reported in the monkey fetus (3); the dose of phenobarbital we used, although adequate to produce sedation, may have been too low to demonstrate the metabolic effect. Anesthetic levels of barbiturate may be required in the infant to detect clinical evidence of protection from asphyxia. Less likely, the fetus and neonate may respond differently to barbiturate.

These data confirm the circulatory redistribution of cardiac output in response to asphyxia described previously in the monkey fetus (1). Although all organ blood flows during asphyxia were reduced on a milliliter per minute per gram basis, there was preferential redistribution of blood to heart and paleoencephalon. The percentage of cardiac output to cerebral hemispheres during asphyxia was maintained, whereas percentage of cardiac output to kidneys, liver, and gastrointestinal tract was decreased, which indicated a relatively greater underperfusion of these organs. There was no difference in response between treated and untreated infants in this study. Our results and those of Cockburn and associates (3) indicate that further study of the modifying effect of phenobarbital pretreatment on asphyxia is needed to clarify the role of several factors including age, barbiturate dose, and organ specificity.

\section{SUMMARY}

The circulatory changes associated with asphyxia and the effects of phenobarbital on these changes in the newborn monkey were studied. Six infants were untreated and eight received phenobarbital during the protocol. Although the treated infants were clinically sedated there were no statistical differences between the two groups with respect to acid-base balance, clinical evaluation of asphyxia, cardiac output, or organ blood flow distribution.

Heart, total brain, and adrenal glands received a greater percentage of cardiac output during asphyxia, whereas kidneys, liver, and gastrointestinal tract received less. Total body oxygen consumption was only slightly lower in the treated infants; individual organ oxygen consumption measurements and/or anesthetic doses of barbiturate may be necessary to demonstrate a protective effect against asphyxia. 


\section{REFERENCES AND NOTES}

1. Behrman, R. E., Lees, M. A., Peterson, E. N., deLannoy, C. W., and Seeds, A. E.: Distribution of the circulation in the normal and asphyxiated fetal primate. Amer. J. Obstet. Gynec., 108: 956 (1970).

2. Buckberg, G. D., Luck, J. C., Payne, D. B., Hoffman, J. I., Archie, J. P., and Fixler, D. E.: Some of the sources of error in measuring regional blood flow with radioactive microspheres. J. Appl. Physiol., 31: 598 (1971).

3. Cockburn, F., Daniel, S. S., Dawes, G. S., James, L. S., Meyers, R. E., Niemann, W., Rodriguez de Curet, H., and Ross, B. B.: The effect of pentobarbital anesthesia on resuscitation and brain damage in fetal rhesus monkeys asphyxiated on delivery. J. Pediat., 75: 281 (1969).

4. Duncan, S. L. B.: The partition of uterine blood flow in the pregnant rabbit. J. Physiol., 204: 421 (1969).

5. Lees, M. H., Bristow, J. D., Way, C., and Brown, M.: Cardiac output by Fick Principle in infants and young children. Amer. $J$. Dis. Child., 114: 144 (1967).

6. Lowry, O. H., Passonneau, J. V., Hasselberger, F. X., and Shulz, D. W.: Effect of ischemia on known substrates and cofactors of the glycolytic pathway in brain. J. Biol. Chem., 239: 18 (1964).

7. Paton, J. B., Fisher, D. E., Saba, T. M., and Behrman, R. E.: Measurement of liver blood flow in the infant monkey. A comparison of methods. Biol. Neonate, 23: 1 (1973).

8. Phibbs, R. H., Wyter, F., and Neutze, J.: Rheology of microspheres injected into circulation of rabbits. Nature, 216:1339 (1967).

Copyright @ 1975 International Pediatric Research Foundation, Inc.
9. Rudolph, A. M, and Heymann, M. A.: The circulation of the fetus in utero. Circ. Res., 21: 163 (1967).

10. Siggaard-Anderson, O.: The $\mathrm{pH} / \mathrm{log} \mathrm{pCO}_{2}$ blood acid-base nomogram revised. Scand. J. Clin. Lab. Invest., 14: 598 (1964).

11. Wechsler, R. L., Dripps, R. D., and Kety, S. S.: Blood flow and oxygen consumption of the human brain during anesthesia produced by thiopental. Anesthesiology, 12: 308 (1951).

12. Hewlett-Packard, Skokie, Ill.

13. Radiometer Division, London Company, Cleveland, Ohio.

14. James G. Biddle Company, Plymouth Meeting, $\mathrm{Pa}$.

15. Minnesota Mining \& Manufacturing Company, Minneapolis, Minn.

16. Technicon Corporation, Tarrytown, N. Y.

17. Model 25601, Nuclear Chicago Corporation, Des Plaines, III.

18. Presented in part at the meeting of the Society for Pediatrics Research, April 30, 1971.

19. The present address of Dr. R. E. Behrman is: Department of Pediatrics, College of Physicians and Surgeons, Columbia University and Babies Hospital, The Children's Medical and Surgical Center of New York, New York, New York.

20. This research was supported in part by DMH Grants nos. 17-344 and 236-12-RD and a grant from the Pharmaceutical Manufacturers Association and the Michael Reese Research Institute. It was performed, in part, while the authors were at the University of Illinois College of Medicine, Chicago, Ill.

21. Requests for reprints should be addressed to: D. E. Fisher, M.D. Department of Pediatrics, Michael Reese Medical Center, 29th St. and Ellis Ave., Chicago, Ill., 60616 (USA).

22. Accepted for publication December 9,1974 .

Pediat. Res. 9: 184-189 (1975)

"Car. factor" deficiency partial thromboplastin time platelets

Printed in U.S.A.

\title{
“Car. Factor” Deficiency Revisited
}

\author{
DIANE M. KOMP(32) \\ University of Virginia School of Medicine, Charlottesville, Virginia, USA
}

\section{Extract}

Three members of a Virginia family with a bleeding disorder were found to have a serum defect in thromboplastin generation similar to the previously reported "Car. factor" deficiency. Sera from three members of the original Car. family did not correct the defect of affected members of the Virginia family. Partial thromboplastin times of Car. deficient individuals and affected members of the Virginia family were normal. Although correction with normal serum is attained in vitro, the serum defect persisted after infusion of fresh frozen plasma.

Platelet function studies of the Virginia family revealed less than $30 \%$ aggregation after the addition of exogenous ADP and disaggregation within $2 \mathrm{~min}$. Evaluation of children with Noonan's syndrome, albinism, and "Portsmouth" syndrome showed coexistent platelet aggregation defects and nonspecific serum defects.

\section{Speculation}

These studies suggest that the Car. factor is nonspecific; the serum defect may result from the interaction of abnormal cellular elements of the blood during clotting of whole blood in glass. This deficiency can be corrected in vitro by the addition of dilute thrombin.
Before the introduction of the partial thromboplastin time (PTT), the thromboplastin generation test (TGT) was used extensively as a screening test for deficiencies of thromboplastin generation. Of the officially recognized plasma coagulation factors, serum defect without plasma defect is produced only by deficiencies of factor IX or X. Various serum defects. have been reported in persons with normal levels of these two factors who do not appear to have inheritable bleeding disorders (2, 9, 15). In 1957, Chirico and McElfresh (8) reported a familial abnormality of thromboplastin generation detected in the serum component of the TGT. This defect was tentatively named "Car. factor" after the Caucasian family of Italian extraction in whom it was detected. The inheritance was most consistent with autosomal dominance; affected family members had moderate to severe bleeding problems.

A Virginia family was found to have a serum defect consistent with the Car. factor deficiency. It is the purpose of this paper to report extended studies that show the nonspecific nature of the Car. factor deficiency.

\section{MATERIALS}

ADP

The sodium salt of ADP trihydrate (25) was dissolved in calcium-free Tyrode's solution to give a concentration of $4 X$ $10^{-5} \mathrm{M}$ 